\title{
ANALISIS IMPLEMENTASI KONSEP COC (CODE OF CONDUCT) DALAM PENYELESAIAN KONFLIK DI LAUT NATUNA UTARA
}

\author{
Rendi Prayuda ${ }^{1}$, Fanesa Angeli ${ }^{2}$ \\ Hubungan Internasional Universitas Islam Riau Indonesia \\ Email: rendiprayuda@soc.uir.ac.id ${ }^{1}$,Fanesaangeli@student.uir.ac.id ${ }^{2}$
}

\begin{abstract}
ABSTRAK
Artikel ini menjelaskan tentang kode etik yang menjadi landasan acuan dalam mengurangi perdebatan kasus konflik di kepulaun Natuna. Sengketa tumpang tindih di kepulauan Natuna telah menjadi persoalan utama dalam hal kedaulatan Negara. Dari perspektif keamanan, maka Indonesia melalui ASEAN berupaya mempercepat penyelesaian Code of Conduct (CoC) di Laut Cina Selatan antara angkatan laut ASEAN dengan angkatan laut Cina. Dengan berlakunya CoC, masing-masing angkatan laut menerapkan mekanisme pencegahan konflik di laut Cina Selatan. Temuan dalam artikel ini menggunakan metode penelitian kualitatif, dengan mengambil kajian literature berupa studi pustaka. Tulisan ini menggunakan perspektif kontruktuvisme dimana adanya keinginan Negara antara Indonesia dan Cina untuk menguasai kepulauan Natuna sehingga tercapainya kedaulatan Negara. Tulisan ini bertujuan untuk menganilasis kajian dalam penyelesaian konflik di Kepulauan Natuna berupa penyelesaian Code of Conduct di Laut Cina Selatan antara angkatan laut ASEAN dengan angkatan laut Cina.
\end{abstract}

Kata kunci: Laut Cina Selatan, CoC (Code of Conduct)

\begin{abstract}
This article describes the code of ethics which is the basis of reference in reducing the debate over conflict cases in the Natuna island Overlapping disputes in the Natuna islands have become a major problem in terms of state sovereignty. From a security perspective, Indonesia through ASEAN seeks to accelerate the completion of the Code of Conduct (CoC) in the South China Sea between the ASEAN navy and the Chinese navy. With the CoC in force, each navy applies a conflict prevention mechanism in the South China Sea. The findings in this article use qualitative research methods, by taking a literature review in the form of a literature study. This paper uses the perspective of constructivism in which there is a desire of the state between Indonesia and China to dominate the Natuna islands so as to achieve state sovereignty. This paper aims to analyze studies in conflict resolution in the Natuna Islands in the form of completion of the Code of Conduct in the South China Sea between the ASEAN navy and the Chinese navy.
\end{abstract}

Keywords: South China Sea, COC (Code of Conduct)

\section{PENDAHULUAN}

Pulau Natuna merupakan kepulauan yang terletak di Kepulauan Riau yang berbatasan dengan Laut Cina Selatan. Natuna terdiri dari tujuh puluh dengan Ibu Kota di 
Ranai. Dilihat dari sejarah, dahulunya Natuna termasuk kedalam wilayah kerajaan Pattani dan kerajaan Johor di Malaysia. Namun, pada abad ke-19 kepulauan Natuna akhirnya masuk kedalam penguasaan kedaulatan Riau dan menjadi wilayah dari Kesultanan Riau. Setelah Indonesia merdeka pada tahun 1986, pemerintah Indonesia resmi mendaftarkan kepulauan Natuna sebagai wilayah kedaulatan Perserikatan Bangsa-Bangsa (PBB). Kepulauan Natuna menjadi jalur strategis dalam hal pelayaran internasional. Dilihat dari letak geografisnya, kepulauan Natuna ditetapkan secara nasional yang mempunyai nilai strategis terhadap penataan ruang yang diprioritaskan dimana usaha dan kegiatannya berdampak besar terhadap kondisi geopolitics dan pertahanan dan keamanan nasional serta regional. Salah satu potensi yang dimiliki berupa pengembangan poltik ekonomi dilihat dari besarnya sumber daya alam yang ada dan berdampak besar terhadap kegiatan perekonomian internasional baik di wilayah bersangkutan mapun di wilayah sekitar.

Secara geografis posisi dan letak kepulauan Natuna sangat meguntungkan karena berada pada posisi silang jalur Pelayaran Internasional. Berbatasan dengan Vietnam dan Kamboja, di sisi selatan berbatasan dengan Sumatra Selatan dan Jambi, di bagian barat berbatasan dengan Singapura, Malaysia, Riau, serta bagian utaranya terletak di bagian Selat Karimata. Sebagai wilayah yang berada di posisi silang, wilayah perairan Natuna juga memiliki peran dan arti geo-politik yang sangat besar karena menjadi titik temu Cina dengan tetangga-tetangganya terutama yang berada di dalam wilayah ASEAN. Dikarenakan Kepulauan Natuna terletak pada posisi silang jalur Pelayaran Internasional, menjadikan wilayah Natuna menjadi sumber konflik antara Indonesia dan Cina.

Kontroversi Natuna mengenai perdebatan kedaulatan Negara diawali dengan Malaysia menyatakan kepemilikan sah terhadap wilayah Natuna. Namun untuk menghindari konflik panjang, Malaysia tidak menggugat konflik tersebut, sehingga Indonesia mampu membangun infrasturktur di kepulauan tersebut. Selepas dari kontroversi yang dihadapkan oleh Indonesia-Malaysia, sentiment bahwa Cina mengklaim wilayah laut Natuna masih menjadi milik mereka. Hal ini ditandai dengan berlayarnya kapal Coast Guard Cina di perairan Natuna, kapal ini memasuki wilayah Zona Ekonomi Eksklusif Indonesia (ZEE) secara illegal.

Salah satu penyebab sengketa Cina dan Indonesia dikarenakan besarnya potensi sumber kekayaan alamnya, menjadi wilayah yang memiliki potensi sumber cadangan energi sekitar 500 juta per barel. Pelanggaran wilayah Zona Ekonomi Eksklusif (ZEE) yang dilakukan oleh kapal Coast Guard Cina di Perairan Natuna tersebut. Claim sepihak yang dilakukan Cina terhadap laut Natuna ditetapkan berdasarkan Sembilan garis putus- 
putus yang ditetapkan di wilayah kepulauan Natuna menjadi bagian dari Cina. Menurut juru bicara Kementrian Cina Geng Shuang, bahwa perairan Natuna termasuk dalam NineDash Line Cina jalur ini membentang dari daratan Cina hingga Fhiliphina, Malaysia dan Thailand. Melalui klaim Nine-Dash Line menjadi penanda batas laut Negara. Nine-Dash Line merupakan Sembilan garis imajiner sebagai penentu kajian historis terhadap kepemilikan Laut Cina Selatan yang disetuji secara sepihak oleh Cina melalui Konvensi Hukum Laut Internasional atau (UNCLOS) United Nation Convention of the Law of the Sea pada tahun 1982.

Pembentukan Nine-Dash Line awalnya muncul sebagai 11-Dash Line. Cina melakukan klaim atas perairan Natuna yang merupakan bagian dari kebijakan pemerintah ketika lepas dari pendudukan Jepang pada tahun 1947. Dalam perkembangannya klaim 11 garis putus-putus menjadi 9 garis putus-putus. Atas dasar tersebut, Cina mengambil kebijakan dalam kepemilikan di wilayah laut Natuna. Berdasarkan Hukum Laut Internasional yang mengatur Zona Ekonomi Eksklusif (ZEE), perairan Natuna menjadi kawasana regional Indonesia sejauh 200 mil. Cina sama sekali tidak berhak atas klaim tersebut. Tidak adanya dasar pengakuan dalam penentuan batas laut di Kepulauan Natuna. Penentuan batas Laut didasari dengan 200 mil dari garis pantai tersebut.

Dalam membahas wilayah kedaulatan Negara, dalam hukum laut internasional terdapat perbedaan mendasar antara sovereignty dan sovereign right. Sovereignty merujuk kepada kedaulatan laut secara garis teritorial, sedangkan sovereign right memberikan hak Negara pemilik pantai untuk mengeksplotasi dan mengelola sumber daya alam di wilayah laut lepas. Tekait klaim Sembilan garis putus-putus, Indonesia harus mampu untuk bersifat tegas dan mempertahankan kesatuan dan keutuhan NKRI. Berikut ini merupakan nine dash line yang diklai oleh Pemerintah China di wilayah Laut China Selatan, yaitu sebagai berikut: 


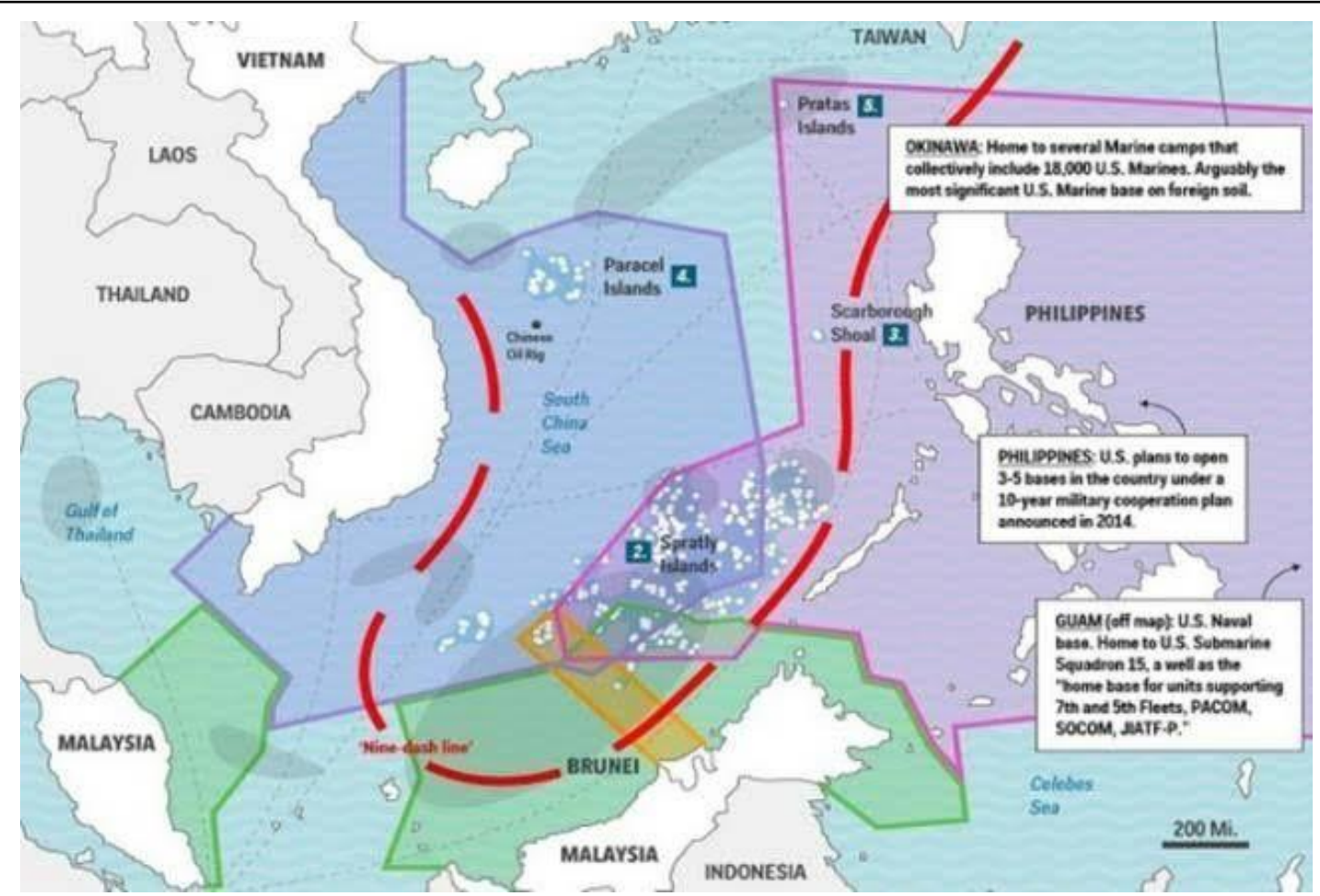

Gambar 1. Nine Dash Line Laut China Selatan

Berdasarkan peta jalur garis putus-putus yang di klaim oleh Cina, wilayah perairan dengan hampir 3 juta kilometer persegi didasari dengan argument traditional fishing zone atau penangkapan ikan secara tradiosional. Terbentuknya Laut Cina Selatan yang menjadi pusat pelayaran, karena dilalui posisi silang jalur perdagangan internasional. Letak gerografis yang strategis dan terbentuknya Negara modern dikawasan ini dengan berbagai perjanjian internasional tentang laut, telah mengubah batas-batas teritorial antar Negara. perbedaan persepsi di antara Negara-negara inilah yang menjadi sumber konflik batas laut. Konflik ini bermula dari legitimasi seajarah pada pulau-pulau yang termasuk dalam Sembilan garis putus batas teritorial Cina di Laut Cina Selatan. Dokumen Issue of South Cina Sea yang terdiri dari kepulauan Parachel yang juga sama-sama di klaim Vietnam dan Taiwan, hingga laut dikepulauan Spratlly dimana Cina bersengketa dengan Fhiliphina, Malaysia, Vietnam dan Brunai Darussalam. Melalui klaim Nine-Dash Line, Cina mengakui perairan wilayah Natuna sebagai bagian dari wilayahnya. Hal ini menjadi problematika oleh pihak Vietnam karena ketidaksetujuan Vietnam serta Fhiliphina terhadap klaim Cina. Vietnam menolak klaim Cina karena kepulauan Parachel serta Sprattly merupakan teritorial kawasan Vietnam.

Dilihat dari letak kepulaun Natuna yang stategis menjadikan kepulauan Natuna memegang peranan penting bagi keberlangsungan ekonomi Negara tetangga, yakni Vietnam, Malaysia, Brunai serta Fhiliphina. Bagi Indonesia sendiri, wilayah kepulauan 
Natuna menyimpan sumber daya mineral berupa gas alam. Cadangan gas di Natuna memang disebut sebagai yang terbesar di Indonesia yaitu sebesar 46,96 TSCF. Saat ini produksi gas di wilayah tersebut baru mencapai 489 MMSCFD. Bukan hanya di sektor gas alam, kepulauan Natuna juga merupakan daerah penghasil minyak bumi yang seolah tiada habisnya. Indonesia memiliki cadangan minyak di Natuna yang diperkirakan mencapai 36 juta barel dengan produksi saat ini sebesar 25 ribu barel per hari. Banyaknya pengeboran minyak lepas pantai yang dilakukan oleh migas diseluruh sumur eksplorasi yang mencapai kisaran 21,8 Triliun Rupiah ini menjadi bukti nyata betapa besarnya kekayaan alam yang dihasilkan di kepulauan Natuna tersebut. Selain itu, Natuna juga terkenal akan penghasil sumber daya perikanan yang mencapai 88 ribu ton. Disamping itu Natuna juga menjadi penghasil komuditas pertanian penting seperti, beras, jagung, kedelai, karet, kelapa, cengkeh dan lainnya.

Oleh karena itu, banyak pihak yang menginginkan kedaulatan dari kepulauan tersebut, mengikutsertakan keterlibatan ASEAN dalam melakukan penyelesaian konflik di kepulauan Natuna. ASEAN telah menerapkan perubahan status DoC (Declaration on the Conduct) menjadi status CoC (Code of Conduct) sehingga kesepakatan perjanjian terkait sengketa wilayah tersebut dapat mengikat pihak-pihak yang terkait. ASEAN juga telah melakasanakan hubungan kerjasama Bilateral yang hingga saat ini masih terus dijalankan sebagai langkah awal dalam penyelesaian konflik di kepulauan Natuna. Dengan tujuan menerapkan peemanfaatan bersama dalam potensi sumber daya alam yang ada diwilayah sengketa oleh masing-masing pihak yang terkait, baik keanggotan ASEAN maupun Negara yang bersengketa. Pembahasan lain mengenai Kepentingan Indonesia Memprakasai Code of Conduct (CoC) of Parties di Laut Cina Selatan telah dibahas oleh Humaltike Kritine (2014). Yang menjelasakan tentang kepentingan Indonesia memprakarsai Code of Conduct (CoC) of Parties.

Indonesia menyatakan bahwa CoC dibutuhkan di Laut Cina Selatan yang kemudian dibuktikan dengan keberanian Indonesia mengeluarkan Zero Draft Code of Conduct of Parties in The South China Sea (Zero Draft COC) yang kemudian diterima secara resmi sebagai rancangan dasar COC. Kepentingan Indonesia memprakarsai CoC dilakasanakan sebagai tujuan agar situasi di Laut Cina Selatan dapat dikendalikan dan mengantisipasi potensi-potensi konflik yangakan terjadi. Faktanya Indonesia telah lebih dahulu dari ASEAN dalam menanggapi situasi di Laut Cina Selatan sehingga perlu adanya pertimbangan-pertimbangan lain yang mendorong Indonesia untuk mengambil keputusan itu yang dapat dilihat dari potensi strategisnya hasil laut dan sumber daya yang dimiliki 
oleh kepulauan Natuna.

Selain itu, pembahasan mengenai penyelesaian konflik di kepulauan Natuna kemudian di perkuat dengan adanya temuan baru berupa Strategi Pemerintah Indonesia dalam Penyelesaian Konflik Klaim Tradisional Fishing Ground Pada Zona Ekonomi Eksklusif Indonesia di Perairan Natuna oleh Republik Rakyat Tiongkok. Tulisan ini kemudian dibahas oleh Sri Wahyuni (2019), yang menjelasakan teori knflik yang dibangun sebagai faktor penyebab konflik klaim Traditional Fishing Ground pada ZEE Indonesia di perairan Natuna. Dalam memenuhi kepentingan nasionalnya, Tiongkok menggunakan kekuasaan untuk memaksakan klaimnya pada wilayah ZEE Indonesia di perairan Natuna. Tiongkok melakukan ekspansi yang di dasarkan pada faktor historis atau hak sejarah pemanfaatan sumber daya ikan di kepulauan pada masa lalu, yang oleh Tiongkok di sebut dengan tradisional fishing ground. Hak sejarah tersebut juga berhubungan dengan klaim nine dash line Tiongkok di Laut Tiongkok Selatan yang yang garis klaimnya bersinggungan dengan wilayah ZEE Indonesia di perairan Natuna.

\section{PEMBAHASAN}

Problematika yang muncul atas konflik antara Indonesia dan Cina dimana pengakuan Cina terhadap wilayah Kepulauan Natuna yang menjadi wilayah Laut Cina Selatan menimbulkan spekulasi terhadap Sembilan jalur Nine-Dash Line dimana jalur tersebut berdampak kepada keterlibatan Negara-negara tetangga seperti Malaysia, Vietnam, Thaiwan dan Fhiliphina menjadi aliansi musuh terhadap Cina. Selain itu, konflik perdebatan Laut Cina Selatan juga berdampak kepada Amerika Serikat. Dimana strategi yang diterapkan Cina dalam mengklaim wilayah Kepulauan Natuna tidak terlepas dari Natuna menjadi sektor penghubung pasar ekonomi Asia dan Eropa melalui pembangun infrastruktur. Keterlibatan peran Amerika dalam jalur Laut Cina Selatan karena adanya kepentingan mempertahankan kekuatannya dalam status internasional. Kepentingan Amerika Serikat terhadap jalur Laut Cina Selatan, Amerika Serikat sebagai Negara homogen dengan meningkatkan kerjasama militer dengan Vietnam seta Fhiliphina. Dengan bantuan Amerika Serikat, Fhiliphina membangun pangkalan militer di kawasan Laut Cina Selatan sebagai penegasan wilayah teriotrial.

Dalam perspektif hukum internasional, tinjauan yuridis yang dimiliki suatu Negara berpusat dalam wilayah kedaulata Negara. Berdasarkan hukum internasional, kedaulatan Negara merupakan suatu kekuasaan mutlak yang dimiliki suatu Negara atas dasar kependudukan serta wilayah beserta isinya yang dimiliki oleh Negara serta diakui oleh 
Negara lain. Berdasarkan konsep kedaulatan Negara menurut Aristoteles, merupakan sebuah mata pisau yang memiliki pertimbangan fungsi objek dan tujuan. Hukum internasional mendefinisikan Negara yang berdaulat merupakan kesatuan yang memiliki penduduk tetap, serta wilayah yang permanen yang tidak dapat diganggu dan dimiliki oleh Negara lain dan serta diakui oleh Negara lain. Perolehan kedaulatan Negara menurut hukum internasional dilihat dari 5 cara suatu negra dapat memporel kedaulatan Negara, (1) pendudukan, (2) preskiripsi, (3) cessi, (4) akresi, dan (5) penaklukan. Perolehan kedaulatan Negara dalam pembentukan organisasi PBB dilihat dari 3 faktor, diantaranya: perolehan kedaulatan Negara didasari oleh perolehan kedaulatan Negara ditetapkan berdasarkan waktu dan kejelasan hukum yang mengatur, perolehan dan penerapan kedaulatan oleh suatu Negara terhadap suatu wilayah tertentu didasarkan oleh hak untuk menentukan nasib sendiri (right of self-determination), dalam kerangka hukum internasional kontemporer penyerahan kedaulatan suatu Negara tidak boleh didasari dengan kekerasan kecuali dengan alasan dan bukti kuat yang sah.

Dilihat dari tinjauan hukum secara yuridis mengenai kepemilikan Kepulauan Natuna, landasan kontinental yang dilihat dari dasar laut dan berjarak sejauh 200 mil dari garis pangkal dan lebar laut territorial yang diukur, sesuai dengan peraturan yang diatur dalam Undang-Undang Pasal 76 ayat 4. Namun, potensi yang dimiliki Kepulauan Natuna memicu konflik antara Cina dengan Indonesia. Di dalam strategi pertahana cina, dikenal dengan two Chines, dimana first island Chines merupakan garisi putus-putus yang melingkupi Kepulauan Kuril, Jepang, Kepulauan Ryukyu, dan Indonesia (KalimantanNatuna). Berdasarkan geografis wilayah Natuna merupakan first island Chines yang strategis bagi Cina.

Permasalahan yang di klaim Cina ialah adanya garis demarkasi berupa adanya garis putus-putus yang ditandai dengn Nine-Dash Line yang mencakup Kepulauan Parachel, Kepulauan Sparaty serta Kepulauan Natuna yang termasuk kedalam wilayah Laut Cina Selatan. Dalam penyelesaian konflik tesebut, diperlukannya adanya hubungan diplomatic dari kedua Negara dalam menyelesaikan sengketa Laut Cina Selatan. Hubungan diplomatic berupa penyelesaian konflik dengan cara penyusunan dokumen berupa Declration on the Conduct of Parties in the South Cina Sea, yaitu meningkatkan kerjasama serta memilihara perdamaian dan stabilitas di Laut Cina Selatan. Namun pada tahapan ini Indonesia masih belum mampu mencapai misi dalam memelihara perdamaian di kawasan Laut Cina Selatan. Penyusunan dokumen DoC hanya mampu memberikan batasan-batasan prilaku kepada para pihak yang terlibat dalam konflik Laut Cina Selatan, sehingga belum mampu 
mencegah suatu perselisahan. Sehingga dibentuknya suatu aturan berupa $\mathrm{CoC}$ (Code of Conduct) secara lebih kongkrit yang membatasi prilaku Negara, serta membentuk dokumen hukum internasional yang lebih mengikat.

Keberhasilan Indonesia bersama ASEAN serta China dalam upaya penyelesaian masalah Laut China Selatan dengan terciptanya Declaration on the Conduct of Parties in the South China Sea pada tahun 2002, dianggap sebagai salah satu implementasi dari perspektif luar negeri Indonesia yang dikenal dengan "Doktrin Natalegawa" (Dynamic Equilibrium). Doktrin tersebut merujuk pada suatu kondisi yang ditandai oleh hubungan antar Negara yang mengedepankan kemitraan dan berlandaskan keyakinan bahwa sangat dimungkinkan untuk dikembangkan suatu tatanan internasional yang baru bersifat win-win solution dan bukan zero - sum. Dilihat dari perspektif keamanan serta kedaulatan Negara, penyelesaian konflik Laut Cina Selatan, Indonesia melalui ASEAN melakukan penyelesaian berupa $\mathrm{CoC}$ (Code of Conduct) dalam menyelesaikan konflik laut. Penerapan $\mathrm{CoC}$ (Code of Conduct), sangat efisien dalam menghindari terjadinya konflik tanpa terjadinya perang. $\mathrm{CoC}$ (Code of Conduct) memiliki aturan hukum internasional yang membatasi setiap Negara yang terlibat dalam kawasan Laut Cina Selatan. Dalam sudut pandang Cina, Cina memiliki kuasa penuh dalam forum multilateral tersebut. Mekanisme yang diberlakukan dalam penyelesain konflik di kepulauan Natuna ialah dengan berfokus kepada mempertahankan keamanan untuk meredam eskalasi konflik untuk tidak meningkat menjadi perang.

Menurut pendapat pakar Pengamat Militer Intelijen dan Pertahanan. Susaningtyas Kertopati, mengungkapkan bahwa, Indonesia melalui ASEAN dapat berupaya mempercepat penyelesaian Code of Conduct $(\mathrm{CoC})$ di Laut Cina Selatan antara Angkatan Laut ASEAN dengan Angkatan Laut Cina. Pihak yang berkepentingan dengan CoC juga bisa lebih dibuka tidak hanya antar-Angkatan Laut, tapi juga bisa antar-Coast Guard dan antar-Angkatan Udara. Jadi, kapal-kapal perang Angkatan Laut, kapal-kapal Coast Guard, dan pesawat tempur Angkatan Udara ASEAN dan Cina semuanya dapat menerapkan mekanisme sesuai dengan kode etik pengaturan khusus yang berfungsi sebagai titik acuan CoC.

Dalam perspektif Hubungan Internasioanal, pendekatan secara yuridis yang dibahas secara legalisasi, ASEAN berupaya menyelesaikan sengketa Laut Cina Selatan dengan berbagai strategi yang membahas Laut Cina Selatan dengan membahasa persoalan ARF (ASEAN Regional Forum). Kenneth W. Abbott et.al (2000) menjelaskan mengenai karakteristik-karakteristik dalam hal hukum internasional yang disebut "legalisasi". 
Karakteristik tersebut dijelaskan melalui tiga dimensi, yaitu: (1) dimensi obligasi, dimana Negara dibatasi oleh aturan hukum, (2) dimensi presesi, menjelaskan tentang kekuasan yang dimiliki oleh Negara, (3) dimensi delegasi, pihak ketiga yang memiliki kekuasaan dalam menjalankan aturan hukum. Menurut penelitian Kenneth W. Abbott et. al. (2000), tidak semua dimensi dapat diterapkan dan dianalisis dalam suatu hukum internasional.

Peran ASEAN dalam menangani kasus Laut Cina Selatan memiliki peran penting dalam terciptanya keamanan dan stabilitas ekonomi. Keterlibatan Negara-negara ASEAN dalam konflik Laut Cina Selatan memiliki peran sebagai peredam konflik dan mampu menjadi penengah dalam kawasan regional. Pada prinsipnya ASEAN perlu Memanfaatkan mekanisme hubungan bilateral Indonesia dan Cina dengan diterapkannya manajemen bersama usaha penangkapan ikan di perairan tersebut antara BUMN Indonesia dan Cina. Dengan tujuan agar penyelesaian konflik dapat diatasi secara damai berdasarkan hukum internasional, termasuk Konvensi PBB tentang Hukum Laut (UNCLOS 1982) dan mengimplemetasikan Deklarasi tentang Prilaku Para Pihak di LCS, guna membangun CoC yang efektif, efisien, dan konsisten dengan hukum internasional dan dikung oleh komuditas internasional. ASEAN juga harus memastikan bahwa ia memainkan peran kunci dalam mengelola perselisihan melalui kerangka multilateral sambil memastikan bahwa ia dapat menyelesaikan perbedaan internal untuk mempertahankan posisi terpadu dalam perselisihan yang dapat diterima oleh semua Negara anggota, serta ASEAN juga harus terlibat proaktif melibatkan Tiongkok dalam membangun kepercayaan dan meningkatkan stabilitas di LCS.

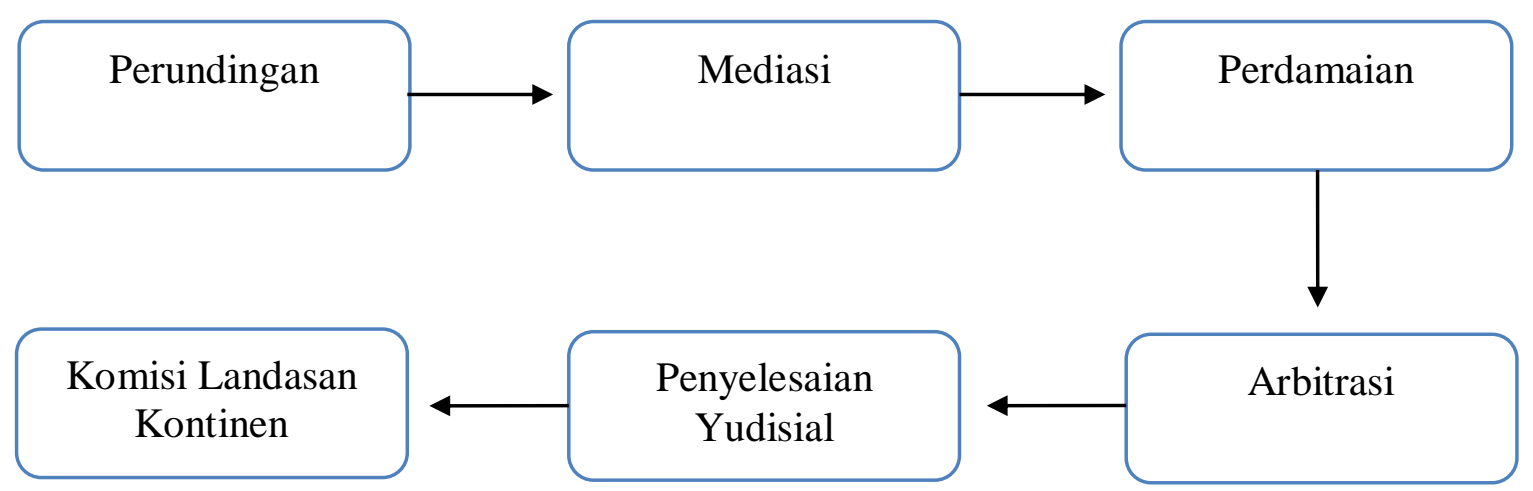

Negara-negara ASEAN lainnya yang mengklaim kedaulatan di wilayah Laut China Selatan belum mencapai kesepakatan. Namun pemerintah Indonesia tetap melakukan upaya Diplomatik dengan pemerintah China, agar sengketa Laut China Selatan tidak meluas sampai ke wilayah kedaulatan Indonesia di Kepulauan Natuna. Dimana dalam hal 
ini kedua Negara telah sepakat untuk mengedepankan Diplomasi dalam menyelesaikan sengketa Laut China Selatan, dengan mengimplementasikan secara penuh dan efektif hal tentang Declaration on the Conduct of Parties in the South China Sea (DOC), yaitu membangun rasa saling percaya, meningkatkan kerjasama, memelihara perdamaian dan stabilitas di laut China Selatan. Dalam menyelesaikan konflik di laut China Selatan, pemerintah Indonesia telah memiliki instrument penyelesaian konflik yang memadai.

Inisiatif mantan Menlu Marty Natalegawa telah mengusulkan draf awal kode atik atau zero draft code of conduct Laut China Selatan dapat dijadikan sebagai senjata ampuh bagi diplomasi Indonesia. Sejauh ini belum ada perundingan untuk menetapkan garis batas ZEE antara China dengan Indonesia di perairan Natuna. Konsep legalisasi menurut Kenneth W. Abbott et. al. (2000), tidak semua dimensi dapat diterapkan dan dianalisis dalam suatu hukum internasional. Dalam obligasi, aturan hukum disepakati oleh tiap Negara-negara anggota. Norma-norma yang diasilkan dalam pesetujuan internasional dipandang sebagai suatu kewajban yang sifatnya mengikat dimana aturan hukum dipandang sebagai kewajiban dan bukan sebagai preferensi. Berdasarkan UNCLOS 1982, Indonesia diakui sebagai Negara kepulauan dengan adanya batas-batas wilayah yang ditentukan dalam UU No 6 tahun 1996 tentang Daftar Kordinat Wilayah Geografis Kepuluan Indonesia.

Batas suatu Negara di laut ditetapkan dengan menarik garis pangkal yang menghubungkan rangkaian titik terluar yang disebut rangkaian titik dasar. Ditentukan dengan melalukan surfey hidrografi yang dilkukan oleh TNI Angkatan Laut yang bertujuan untuk mendapatkan informasi guna menunjang pembangunan di daerah masing-masing pulau. Sebagaimana Angkatan Laut Indonesia memiliki peranan dalam mempertahankan kedaulatan Negara. Dimana konsep dari TNI itu sendiri ialah peran universal, yakini: peran militer, peran diplomasi dan peran polisionil. Berdasarkan studi kasus yang dibahas hubungan Indonesia dengan Tiongkok cenderung berpotensi berkonflik karena ambiguitas Tiongkok yang mana nine-dash line nya terbilang mencapai Pulau Natuna Indonesia. Meski tidak pasti terkait klaim tersebut, Indonesia berusaha untuk tetap menjadi mediator namun juga mempertahankan status quo Pulau Natuna.

Dalam kaitannya ketegangan yang terjadi dikawasan tersebut ASEAN perlu bekerjasama dengan Cina dengan memanfaatkan mekanisme hubungan bilateral Indonesia dan China. Jika manajemen bersama ini berhasil, maka Indonesia dapat juga mengundang Negara lain yang ikut meng-klaim Laut Cina Selatan untuk merubah konflik menjadi keuntungan bersama. Dari perspketif diplomasi, kedudukan wilayah ZEE Indonesia telah 
di tetapkan oleh hukum internasional melalui UNCLOS 1982. Diplomasi luar negeri yang diterapkan oleh Indonesia saat ini ialah berfokus kepada implementasi kebijakan pemerintah untuk lebih mengedepankan diplomasi dan negosiasi dengan tetap memprioritaskan kepentingan nasioanal Indonesia. Dengan demikian, Kementerian Pertahanan (Kemhan) dapat menindaklanjuti dengan diplomasi pertahanan, Mabes TNI menindaklanjuti dengan diplomasi militer, dan Mabesal menindaklanjuti dengan diplomasi angkatan laut. Untuk itu, sangat penting dilakukan pertemuan menteri pertahanan kedua Negara dan bahkan pertemuan bilateral di antara Panglima Angkatan Bersenjata dan pertemuan bilateral Panglima Angkatan Laut. Dengan memanfaatkan mekanisme hubungan bilateral antara Indonesia dan Tiongkok, konflik di perairan Natuna dapat diselesaikan dengan mekanisme manajemen bersama yang saling menguntungkan (win-win management).

Dinamika konflik LCS telah melahirkan kebijakan-kebijakan dengan tujuan sebagai respon terhadap persepsi ancaman yang dimiliki Negara dan juga untuk menjaga stabilitas keamanan Negara. Tujuan utama dari berbagai kebijakan pertahanan Indonesia adalah sebagai tindakan preventif untuk mencegah terjadinya keadaan yang tidak diinginkan. Selain itu kebijakan pertahanan juga dilaksanakan untuk menjaga situasi keamanan dan kedaulatan Indonesia serta pertimbangan kepentingan nasional Indonesia. Tingginya intensitas konflik di LCS menjadikan Indonesia sangat mewaspadai kemungkinan gangguan yang dapat timbul dari konflik tersebut. Tindakan pencegahan merupakan aplikasi dari kebijakan pertahanan Indonesia yang diperlukan untuk menangkal segala kemungkinan gangguan yang akan ditimbulkan oleh konflik LCS.

Status Laut Cina Selatan yang masih menjadi polemic kedaulatan Negara dalam status tinjauan hukum laut internasional telah didasari oleh aturan hukum berupa adanya tinjauan hukum laut (UNCLOS 1982) yang menetapkan batasan-batasan laut territorial. Dalam kasus Laut Cina Selatan khususnya Kepulauan Natuna, dimana Cina menetapakan klaim terhadap wilayah atas dasar nine-dash line nya terbilang mencapai Pulau Natuna Indonesia. Pentingnya diberlakukan $\mathrm{CoC}$ (Code of Conduct) di Laut Cina Selatan untuk menyelesaikan perdebatan konflik yang terus menerus terjadi di Kepulauan Natuna, dimaksudkan dengan tujuan untuk memudahkan ASEAN bernegosiasi dengan Cina terkait penyelesaian konflik klaim Laut Cina Selatan. Dimana, diharapakan dapat menyatukan presepsi bersama dalam tinjauan penyelesaian sengketa di wilayah perairan tersebut. Luaran dari diberlakukannya $\mathrm{CoC}$ (Code of Conduct) ialah dapat mengahargai prinsipprinsip Fredom of Navigation, Zone of Peace dan Neutrality yang sejalan dengan prinsip- 
prinsip Hukum Internasional, ASEAN charter, Piagam PBB, dan UNCLOS. Selain itu, Negara anggota ASEAN harus mencegah terjadinya provokasi yang dilakukan oleh Negara angota ASEAN dengan Cina dan antara Cina dengan Negara lain di luar keanggotaan ASEAN. Serta, Indonesia dan Cina harus melakukan kesepakan secara kolektif dan terbuka.

Mengingat pentingnya keamanan maritime, terutama dalam kaitannya dengan Negara-negara anggota ASEAN, pencegahan konflik maritime menjadi tanggung jawab semua bangsa dan komunitas internasional, dan mengharuskan Negara-negara diluar mupun didalam kawasan dapat bertindak dengan rasa membangun kepercayaan satu sama lain, aktif bekerjasama demi menjaga stabilitas wilayah dan kedaulatan Negara. Untuk mencegah konflik di Laut Cina Selatan, ASEAN harus mampu menjaga kedaualatn atas kawasan di wilayah tersebut.

Negara-negara dikawasan harus secara aktif bekerjasama, untuk memilihara perdamaian, stabilitas dan mempromomosikan penyelesaian damai atas sengketa maritime berdasarkan hukum laut internasional yang telah diatur dalam UNCLOS. Membantu dalam implementasi inisatif dan proyek kerja sama maritime atas dasar kepatuhan terhadap hukum dan perjanjian internasional, serta menyelaraskan kepentingan bersama, memperkuat infomasi dan menjalankan kerjasama dianta pemerintah, organisasi internasional, dan para ahli dibidang lainnya untuk saling berkontribusi memelihara stabilitas kawasan tersebut. Dengan adanya komunitas ASEAN khususnya komunitas politik dan keamana ASEAN, mampu berperan dalam menjaga perdamaian dan stabilitas kawasan, termasuk mampu menciptakan perdamaian dan stabilitas di Laut Cina Selatan yang memiliki nilai dan potensi yang strategis.

\section{KESIMPULAN}

Berdasarkan penjelasan dalam pembahasan, maka dapat disimpulkan bahwa analisa Implementasi konsep CoC (Code of Conduct) dalam Penerapannya Terhadap Penyelesaian Konflik di Kepulauan Natuna meliputi:

1. Konsep $\mathrm{CoC}$ (Code of Conduct) merupakan kode etik atau aturan yang berlaku dikawasan perairan khususnya di Laut Cina Selatan yang tujuaannya untuk menyelesaikan perdebatan konflik yang terus menerus terjadi di Kepulauan Natuna, dimaksudkan dengan tujuan untuk memudahkan ASEAN bernegosiasi dengan Cina terkait penyelesaian konflik klaim Laut Cina Selatan. 
2. Dalam pengimplementasian konsep $\mathrm{CoC}$ (Code of Conduct) dilakukan dengan cara memanfaatkan mekanisme hubungan bilateral antara Indonesia dan Tiongkok, konflik di perairan Natuna dapat diselesaikan dengan mekanisme manajemen bersama yang saling menguntungkan (win-win management).

3. Diharapkan dengan di terapkannya konsep CoC (Code of Conduct) dalam penyelesaian konflik di Kepulauan Natuna dapat menemukan kejelasan terhadap status kedaulatan di Kepulauan Natuna tersebut.

\section{DAFTAR PUSTAKA}

\section{Jurnal}

Agus Haryanto. 2017. Implikasi Declaration of Conduct Laut Tiongkok Selatan Terhadap Proses Penyelesaian Sengketa. Vol. 24 No. 1.

Amy Debora. 2018. Pola Diplomasi Midle Power Indonesia dalam Meredam Ekslasi Konflik Laut Cina Selatan Tahun 2014-2017

Arifianto, A. Politik Indonesia Dalam Konflik Laut Cina Selatan Blok Natuna.

Damastuti, T. A., Hendrianti, R. C., Laras, R. O., \& Agustina, R. (2018). Penyelesaian Sengketa Ilegal Fishing Di Wilayah Laut Natuna Antara Indonesia Dengan China. Jurnal Reformasi Hukum

Dwijaya Saviola. 2019.Konflik Laut Cina Selatan:Peta Geopolitik Aliansi dan Musuh Negara yang Terlibat.

Ela Riska. 2017. Diplomasi Maritim Indonesia terhadap Aktivitas Penangkapan Ikan Ilegal (Ilegal Fishing) oleh Nelayan Cina di ZEE Perairan Kepulauan Natuna. Vol. 3 No 2.

Habib Rexa. 2017. Penyelesaian Multilateral terhadap Sengketa Laut Cina Selatan.

Nadiah Oryza Shabrina. 2014. Perubahan Respon Indonesia terhadap Klaim NINE-DASH LINE Tiongkok yang Melewati Perairan Natuna. Vol 43 No.17

Purbawanti, N. N. S. (2016). Pengaruh Konflik Laut China Selatan Terhadap Stabilitas Keamanan Di Indonesia

Rigo, S. (2017). Pengaruh Konflik Laut China Selatan Terhadap Kebijakan Pertahanan Indonesia (Doctoral dissertation, Universitas Andalas).

Sahrasad, H. (2015). Konflik Laut China Selatan: Rivalitas China-AS dan ASEAN. Konfrontasi: Jurnal Kultural, Ekonomi Dan Perubahan Sosial, 4(2), 34-45.

Salim, L. L. P. Peran Diplomasi Maritim Indonesia Dalam Penyelesaian Konflik Laut China Selatan (LCS).

Saragih, H. M. (2018). Strategi Indonesia Dalam Menghadapi Konflik Laut China Selatan. 
Sigit Riyanto. 2012. Kedaulatan Negara dalam Kerangka Hukum Internasional Kontemporer.

Sumarwan, U. (2015). Analisis Kedaulatan Indonesia Di Kawasan Perairan Natuna.

Tampi, B. (2018). Konflik Kepulauan Natuna Antara Indonesia Dengan China (Suatu Kajian Yuridis). Jurnal Hukum Unsrat 